\title{
Examining the Independent Audit Committee, Managerial Ownership, Independent Board Member and Audit Quality in Listed Banks
}

\author{
Hisar Pangaribuan ${ }^{* 1}$, Jenny Sihombing ${ }^{1}$ and Oluwatoyin Muse Johnson Popoola ${ }^{2}$ \\ ${ }^{1}$ Adventist University of Indonesia, Jl. Kol. Masturi 288, Bandung 40559, Indonesia \\ 2 Tunku Puteri Intan Safinaz School of Accountancy, Universiti Utara Malaysia
}

\begin{abstract}
This research examines the effects of the independent audit committee on the relationship between managerial ownership and independent board member on audit quality in the Indonesian listed banks. Primarily, the study examines the direct relationship of managerial ownership, independent board member and independent audit committee on the audit quality of listed banks in the Indonesian Stock Exchange. Also, the current study explores the mediating effect, indirect effect, of the independent audit committee on the relationship between managerial ownership, independent board member, and audit quality in the listed banks in Indonesia. The results show that the independent board member has a significant impact on the independent audit committee and the audit quality. The study reveals that managerial ownership does not influence audit quality. The adoption of the independent audit committee with a long tenure of years can be potentially risky and less creative. As a result, their oversight functions may be in jeopardy, impaired or reduced performances. The research findings reveal no significant indirect effects of the independent audit committee on the relationship between managerial ownership, independent board member and audit quality in the banks listed in IDX. Independent board members need to renew the appointment of the independent audit committee members to improve the quality of the oversight functions undertaken by the audit committee, and hence, enhance audit quality.
\end{abstract}

Keywords: Managerial Ownership, Independent Board Member, Independent Audit Committee, Audit Quality, Banking Sector

JEL Classification: M40, M41, M42, M49

Paper Type: Research

* Corresponding author: E-mail: pangabhsr@gmail.com, Phone: +62-8170296678; Fax: +6222-2700161 


\section{INTRODUCTION}

The impact of adverse report emanating from the Indonesian banking system had resulted in the government's decision to effect closure of several banks. As rescue effort in 1999 and 2000, the government held the recapitalisation of the 18 banks owned by the central and local government in Indonesia. Banks should be able to function as an agent of trust, an agent of development and agent of service (Docherty \& Viort, 2014). The financial system in Indonesia is fundamentally dominant in the banking sector, and the macroeconomics strongly influenced by the banking system (Kuncoro \& Suharjono, 2012). The Banks, therefore, have a significant contribution in supporting the country's economy (Choudhry, 2011).

Financial Statements represent a company's financial records during an accounting period, which also describe the performance of the company (Subramanyam, 2014). Concern on the auditing services has been on the increase lately, especially for public companies. Audit quality remains the primary concern of auditing services that are reflected in the audit report issued by the independent statutory auditor (Beisland et al., 2015). Audit quality is essential because quality audit means that the audited financial statements guarantee fair presentation. It is argued that the audit quality has a significant impact on the quality of information disclosure (Nosheen, 2013), reduce the uncertainty and the noise in financial reporting (Balsam, 2002).

An audit quality delivers additional impetus or values for the capital market since investors and other stakeholders often use the audited report and financial statements to make investing and useful decisions. Most often, the market reacts to the published audited financial statements (Sudsomboon \& Vssahawanitchakit, 2009), and quality audit could reduce the underpricing on shares outstanding (Beisland et al., 2015). A quality audit has an impact on the better implementation of good corporate governance (Griffin et al., 2008) and also on the better information disclosure (Muhamad et al., 2009). The application of good corporate governance includes quality audit, which has a positive influence on disclosure and thus, reduces the level of information asymmetry (Silveira \& Barros, 2006). Moreover, it is recognised that the audit failure creates a higher chance of litigation, bad reputation, low audit fee, and degeneration of corporate value. The practical implication of this study presupposes that the audit quality has an impact on both the auditor and auditee (Taqi, 2013).

Favere (2000) study on the audit quality found the need to improve several areas such as legal aspects of audits, advanced professional auditing, and skills to increase the level of audit quality in ASEAN countries including Indonesia. On the other hand, the increase in managerial ownership gives greater power to management in directing and overseeing the company activities and contributing to the appointment of an external auditor to give impact on audit quality (Kane \& Velury, 2005). The primary instrument that has an essential role in corporate oversight is the board. The existence of the board, especially independent board is expected to provide assurances for the implementation of corporate governance, especially those related to the protection of investors. The presence of an independent board within the company governance is commendable and thus motivate and encourage the shareholders in overseeing the activities of the company. The board establishes an audit committee and assist them in their supervisory function. In Indonesia, the audit committee consists of at least three persons including an independent commissioner of the issuer and public company (Otoritas Jasa Keuangan Republik Indonesia, No. 55, 2015). The role of the independent board in supervisory and advisory 
capacity to the independent audit committee is critical, valuable and hence, a positive impact on audit quality (Hay et al., 2008).

The audit committee has an essential role in overseeing the financial reporting process, including the appointment of external auditors. The existence of an independent audit committee contributes to better supervision and control and thus, improves the audit quality (Mohamed \& Mohamed, 2012). Open communication between the audit committee and external auditor is necessary to improve the audit quality and transparency of the report (Murphy, 2014). In addition, access to information and unhindered communication assist the audit committee in evaluating the competencies of audit firm during the course engagement (Brooke, 2014). Prior literature indicates a significant positive correlation between audit committee characteristic and audit quality (Yasin \& Nelson, 2012). Based on the background and motivation of the current study with emphasis on audit quality, it is essential to fill a gap through the conduct of empirical research on managerial ownership, the independent board member, the independent audit committee and audit quality the banking companies in Indonesia. This research aims to examine the influence of independent audit committee on the relationship between managerial ownership, the independent board member, and audit quality in the Indonesian listed banks especially, and developing countries in general.

\section{LITERATURE REVIEW, THEORETICAL FRAMEWORK AND HYPOTHESES DEVELOPMENT}

\section{$2.1 \quad$ Literature Review}

The doctrine of separate legal entity is an eye-opener, a motivator and a catalyst that buttresses the essentialities, the real actors, for the current study. This doctrine affirms unquestionably that a company is separate and distinct from its members. In essence, the doctrine implies a business entity is separate from the owner(s), which means the responsibilities of management is distinct and separate from the owner. This position was in agreement with the study of Belkaoui (2004). According to the Agency theory, most often problem arises when there is a conflict of interest between the owner and manager of the company (Shen \& Chih, 2007). There is a need for independent third party to act as a mediator between the principal (as represented by the owner) and the agent (as proxied by the manager) to ensure the agent complies and acts in the best interests of the principal. The use of an independent statutory auditor is a mechanism to restrict the agents from acting arbitrarily. The quality of the audit and the underlying audited financial information are an essential element to other parties for useful decision making. The quality of financial information is necessary to increase the confidence of the users of financial information, including investors (Murphy, 2014).

De Angelo (1981) defined quality audit as the ability of the auditor to find and disclose the infringement on their clients' report, which has been adopted by many other researchers (Velnampy et al., 2014; Hapsoro, 2012). The ability to find infringements depends on the technical ability and competence of the auditor (Brooke, 2014). The larger the size of the public accountant office, the better the audit quality that is produced based on existing regulations (Beisland et al., 2015). Based on the preceding description, the quality of the audit is increasingly seen to be vital as pre-requisite meant to increase the confidence of various parties that will be presented with financial information. The management of the company acts in a way that benefits both the agent and the owner through effective 
monitoring (Peni \& Vähämaa, 2012), and thus, increase the performances of the company (Al-Hussain, 2009).

\subsection{Theoretical framework and Hypotheses Development}

\subsubsection{Managerial Ownership and Audit Quality}

The ownership structure has different motivations for monitoring organisation. When the owner also functions as management in the company, the opportunistic behaviour of the management is bound to decrease. Such a manager is expected to act on the principal's instructions. Invariably, the manager will be motivated to perform efficiently and effectively, and this mitigates the agency problems in the company. In such a circumstance, the management gives input to the audit committee as regards the public accounting firm for engagement in the audit task. The increasing number of managerial ownership means that the management has a more considerable influence on the voting power, which includes the ability to influence the selection of the external auditor for the organisation. Thus, by participating in the engagement process of the external auditor, managerial ownership will no doubt affect the audit quality (Kane \& Velury, 2005).

The appointed auditor in the assignment of auditing is expected to provide an excellent quality of audit, thereby increases the confidence and trust from various parties associated with the company (Griffin et al., 2008). The ownership structure influences the decision of the company, which further affects the quality of the audit. It is noted that managerial ownership has a positive relationship with the quality of audit as reflected in the selection of a public accounting firm (Limpt, 2011). When the number of managerial ownership increases, then the company's control through the engagement of a big audit firm also increases (Kane \& Velury, 2005). The increasing number of managerial ownership will impact audit quality. Based on the extant literature, the hypothesis is formulated thus:

$\mathrm{H}_{1} \quad$ Managerial ownership has a significant impact on audit quality in the Indonesian listed banks.

\subsubsection{Independent Board Member and Audit Quality}

The independent board in the financial industry and other industries have similar or identical functions, namely: supervisory and instruction to top-level management and decision makers (Harris \& Raviv, 2008). However, the banking industries possess large numbers of the independent board members compared to other industries because of tighter monitoring and controls of bank activities (Adams, 2011). There is a perspective in the banking industry that an independent member of the board is more likely to experience attendance related problems at the board meeting (Adams \& Ferreira, 2011). Another deficiency of the existence of the independent board member relates to lack of access to relevant and quality information (Coles et al., 2008; Lehn et al., 2009). A school of thought suggests that in reality, adherence to measuring independence of an independent board member in the banking industry is complicated. This is because the board member may be the customer or somehow related to the bank management or owner (Graham et al., 2011).

The role of the company's board as advisory and supervision could not be overemphasised. The composition of the independent board member is essential and hence required for more effective supervisory and advisory functions (Hermalin \& Weisbach, 
2003). The larger the number of independent member of the board, the more effective the supervision, and thus creating higher values (Andres \& Vallelado, 2008). The prior literature recommends specific measures must be undertaken to improve the functions of the board (Kirkpatrick, 2009). When the size of the audit firm is used as a proxy for audit quality, the characteristics of the board and its independence have significant effects on the audit quality (Hay et al., 2008). In such a situation, the board will cooperate with the audit committee in selecting qualified audit firms in obtaining a better audit quality. In order to protect the reputation and to avoid litigations resulting from the low quality of audit, the board as a matter of policy will appoint a responsible audit firm. The more independent the board members, the more likely emphasis on better audit quality (Carcello et al., 2002). The increase in the number of the independent board members will improve the audit quality. Based on the extant literature, the hypothesis is formulated thus:

$\mathrm{H}_{2}$ Independent board member has a significant impact on audit quality in the Indonesian listed banks.

\subsubsection{Managerial Ownership and Independent Audit Committee}

The audit committee is formed to make relevant recommendations aimed at improving the quality of financial reporting and to conducting effective monitoring, which includes financial reporting (Hamdan et al., 2013). The presence of the audit committee presupposes the presentation of a reliable financial statement such as reducing errors, avoiding misstatements, and reducing deviations and other unethical practices in the report and financial statements. The audit committee is assigned to assisting in the improvement of the quality of information flows between company owners and managers (Rouf, 2011). When there exists a significant size of an independent audit committee members, it ushers in a better commitment to control, and implementation of supervisory functions will be better, and goal setting will be more comfortable to achieve.

The ownership structure possesses the ability to affect the operational activities of the company. The entities or individuals who hold shares of a particular company acquires the voting right to take part in corporate decision making. In the company where there is a reasonable level of managerial ownership, there will exist better operational management, and the disclosure of information will be applied more adequately. The effect makes information asymmetry becomes smaller (Nakhodchari \& Garkaz, 2014). In a situation where management also acts as owner, management should be in coordination with the board members in appointing an independent member of the audit committee so that supervision of financial reporting and audits by the audit committee can efficiently be done. Furthermore, it can be argued that the improvement of managerial ownership will increase the number of independent member of the audit committee. The increasing number of independent audit committee members is expected to improve the oversight functions in the process of presenting the corporate financial statements. Based on extant literature, it is hereby hypothesised as follows:

$\mathrm{H}_{3} \quad$ Managerial ownership has a significant impact on the independent audit committee in the Indonesian listed banks.

\subsubsection{Independent Board Member and Independent Audit Committee}

According to the financial services authority regulation states: "in order to support the effective implementation of tasks and responsibilities, the board shall establish an audit 
committee and may establish other committees" (The Financial Services Authority of the Republic of Indonesia, No. 55/POJK.04/2015) to enhance financial reporting and the quality of the audit. The audit committee in Indonesia consists of at least three members including the independent member of boards of the issuer or public company. The audit committee is responsible for reviewing the financial information, including compliance with laws and regulations.

The audit committee is also responsible for reviewing the audit implementation by the auditor and overseeing the follow-up implementations by the directors based on the auditor's findings (Capital Market Supervisory Agency, Decision of the Chairman of Bapepam - LK No. Kep-643 / BI / 2012). The role of the audit committee in ensuring the quality of financial reports has become the subject of public discourse since the society drew attention to accounting scandals (Kusnadi et al., 2016). As one of the corporate governance mechanisms, the existence of an audit committee has the potentials to reduce the practice of fraud and manipulation in the financial statements (Shen \& Chih, 2007).

The board is responsible for ensuring that the established committee to perform its functions efficiently and effectively. As recognised by Baxter and Cotter (2009) in their study, an independent audit committee is perceived to be more effective in financial reporting supervision. To monitor the company's operations and financial reporting supervision, the company needs the services of an independent board member (Kirkpatrick, 2009), the independent board member will form supporting committees for monitoring, including the audit committee to function more effectively and independently. It could be argued that the increase in the number of independent board members will increase the independence of the audit committee. Thus, the hypothesis is formulated as follows:

$\mathrm{H}_{4}$ Independent board member has a significant impact on the independent audit committee in the Indonesian listed banks.

\subsubsection{Independent Audit Committee and Audit Quality}

The audit committee plays a crucial role in determining the rotation of auditors who will perform the auditing services (Hagenbaugh, 2003). The existence of the audit committee is perceived as a mechanism that can reduce the level of asymmetry of information and improve the quality of publicly presented financial information (McDaniel et al., 2002). The demand to improve audit quality through the role of the audit committee has been on the increase (Murphy, 2014). Regular communication between the audit committee and the public accounting firm needs to be encouraged and effective regarding audit quality indicators aimed at improving audit quality (Brooke, 2014).

Audit fees tend to be higher with big audit firm compared to the smaller audit firm because the big audit firm (as represented mostly by international audit firms) is deemed to produce a better quality of audit compared to the small audit firm. Thus, the size of an audit firm is frequently used in measuring the audit quality (Hapsoro, 2012; Kane \& Velury, 2005). Yasin and Nelson (2012) study revealed the existence of a significant and positive correlation between the independent audit committee and audit quality. An independent audit committee will work more effectively in financial supervision and engagement of the external auditors who will examine and report on the financial statements prepared by the management. The participation in the evaluation and engagement process faithfully represented are the sine qua non to resulting in better audit quality (Vlaminck \& Sarens, 
2013). Furthermore, a prior study found that the independent audit committee members can improve the effectiveness of the supervision of corporate financial reporting practices through the selection of an external auditor, and hence, impacts the audit quality (Hamdan et al., 2013). Granting the extant literature review, the hypothesis as formulated is as follows:

$\mathrm{H}_{5}$ Independent audit committee has a significant impact on audit quality in the Indonesian listed banks.

\subsubsection{Independent Audit Committee on Managerial Ownership and Audit Quality Independent Audit Committee on Independent Board Member and Audit Quality}

As stated in Hypotheses $\mathrm{H}_{3}, \mathrm{H}_{4}$, and $\mathrm{H}_{5}$ of the study, there is a positive significant relationship between managerial ownership, independent board member, and independent audit committee on one part, and a positive significant relationship between the independent audit committee and audit quality on the other part. Thus, this study asserts that independent audit committee mediates the relationship between managerial ownership, independent board member and audit quality in the Indonesian listed banks. It is, therefore, hypothesised as follows:

$\mathrm{H}_{6} \quad$ Independent audit committee mediates the relationship between managerial ownership and audit quality in the Indonesian listed banks.

$\mathrm{H}_{7} \quad$ Independent audit committee mediates the relationship between independent board member and audit quality in the Indonesian listed banks.

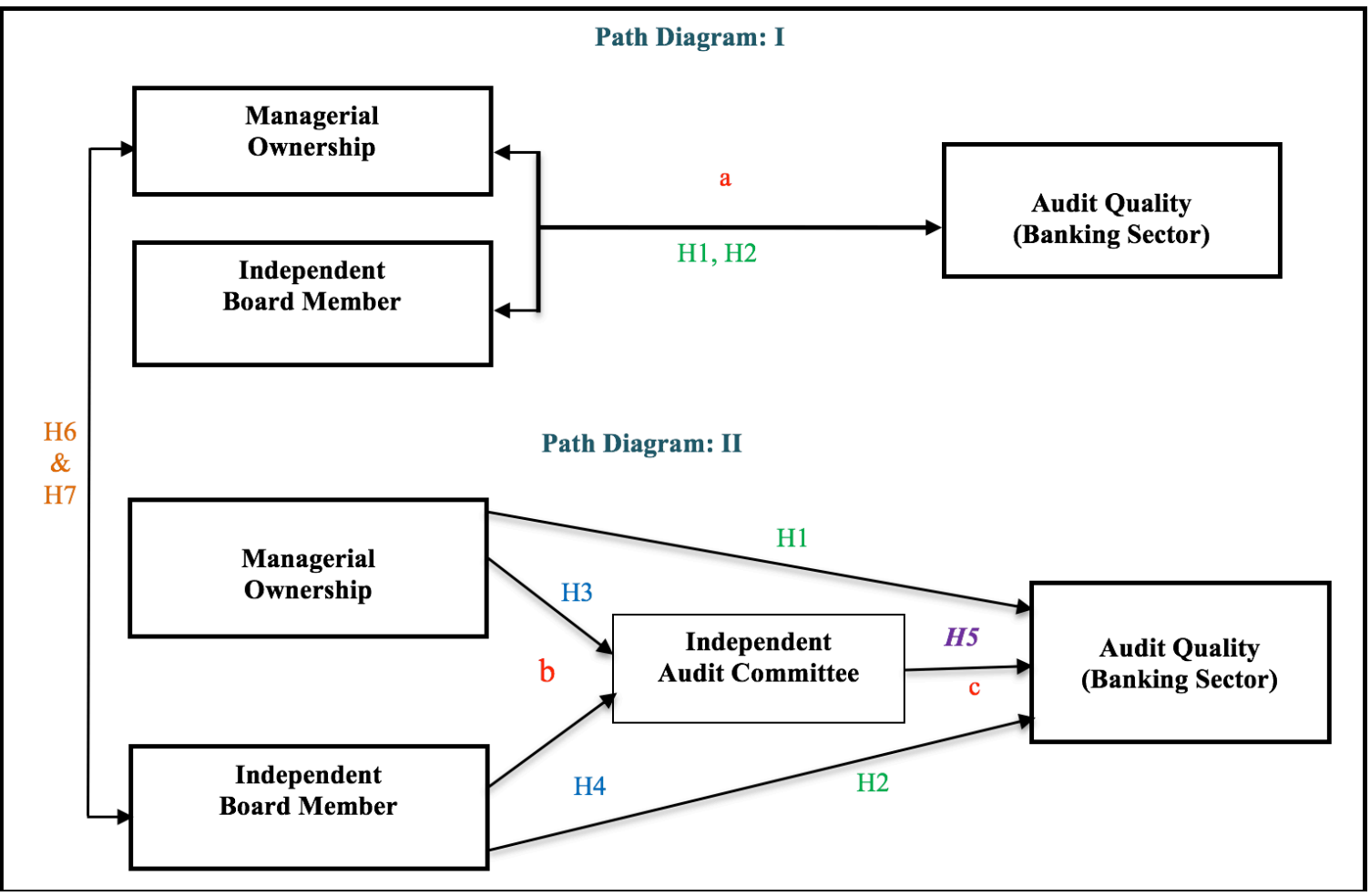

Figure 1. Theoretical framework and Hypothesis development of the Study Source: Adapted from Popoola (2014); and Fritz and MacKinnon (2008) 
Specifically, Figure 1 summarises the theoretical framework and hypothesis of this study. Path diagram (I) denotes the direct effect of managerial ownership and independent board member on audit quality. Path diagram (II) signifies the indirect effect of managerial ownership, and independent board member on audit quality through the mediator variable - independent audit committee. Individually, Hypotheses $\mathrm{H}_{1}$ and $\mathrm{H}_{2}$ in the Path diagram (I) embody the hypothesised relationships between managerial ownership, and independent board member on audit quality. In the Path diagram (II), Hypotheses $\mathrm{H}_{3}$ and $\mathrm{H}_{4}$ represent the hypothesised association between managerial ownership and independent board member on the independent audit committee. Hypotheses $\mathrm{H}_{6}$ and $\mathrm{H}_{7}$ are exemplified by the two path diagrams, (I) and (II), considered as the total effect.

This study aligns with the conditions set by Baron and Kenny (1986), adopted by Popoola (2014) and Fritz and MacKinnon (2008) for path analysis. In order to establish mediation, four conditions as noted by the prior study of Baron and Kenny (1986) must be met. These are (1) The independent variables of managerial ownership, and independent board member must be significant in relation to the dependent variable of audit quality, and this is represented by (a) in Path Diagram I; (2) The independent variables, managerial ownership and independent board member, must be significant in relation to the mediating variable, independent audit committee, as represented in (b) of Path Diagram II; (3) The mediating variable, independent audit committee, must be significant in relation to the dependent variable, audit quality as represented by (c) in Path Diagram II, and (4) In controlling the effects of the independent audit committee on the audit quality, the effect of the managerial ownership and independent board member on the audit quality should not be significant.

\section{RESEARCH METHOD}

\subsection{Population, Sample size and Operationalisation of Variables}

This research is a descriptive verification business research with explanatory hypothesis testing which provides conclusions to address the problems directly (Sekaran \& Bougie, 2010). This research provides an overview of the occurring phenomenon and to explain the influence of variables through hypothesis testing to understand the implication of the problem (Sreejesh et al., 2014). The research population was banking companies listed on IDX, and the samples were Indonesian banking companies listed on the IDX, which are consistently issuing their annual report during the year of 2010 to 2015 . Out of 41 banks listed on IDX, 12 banks listed after 2010 were excluded, and only 29 banks were used as a sample of this research.

The type of research adopted in this study is quantitative, and the data was from secondary sources, which is obtained from the annual reports of the Indonesian listed banks and thus, included as a sample. The data collected as the variables in this research are in the form of a percentage of managerial ownership, the number of an independent board member, number of the independent audit committee and list of the public accounting firms that perform audit services of the respective bank (i.e., the big-four and non-big-four audit firm). The operational definition of the variables is presented in Table 1. 
Table 1. Operational Definition of the Variables

\begin{tabular}{|c|c|c|}
\hline Variables, Definition and References & Indicators & Scale \\
\hline $\begin{array}{l}\text { Managerial ownership: ownership of shares by the management } \\
\text { of the company (Wahba, H. 2014; Santanu et al., 2007; Kane \& } \\
\text { Velury, 2005). }\end{array}$ & $\begin{array}{l}\text { Percentage shares owned } \\
\text { by the manager of the bank } \\
\text { concerned (MgrOwn). }\end{array}$ & Ratio \\
\hline $\begin{array}{l}\text { Independent board: members of the board who do not have a } \\
\text { relationship in financial, management, share ownership and or } \\
\text { family relationship with another member of management, that is } \\
\text { not affected by the other parties to act independently (RachDi \& } \\
\text { Ameur, 2011; Adams \& Mehran 2008; Carcello et al., 2002; } \\
\text { Velnampy et al., 2014). }\end{array}$ & $\begin{array}{l}\text { The number of } \\
\text { independent board } \\
\text { members in certain periods } \\
\text { (IndBodM). }\end{array}$ & Ratio \\
\hline $\begin{array}{l}\text { Independent audit committee: members of the audit committee } \\
\text { who do not have a relationship in financial, management, share } \\
\text { ownership and or family relationship with another member of } \\
\text { management that is not affected by the other party to act } \\
\text { independently (Hamdan et al., 2013; Yasin \& Nelson, 2012). }\end{array}$ & $\begin{array}{l}\text { The numbers of audit } \\
\text { committee members are } \\
\text { independent in certain } \\
\text { periods (IndAudC). }\end{array}$ & Ratio \\
\hline $\begin{array}{l}\text { Audit quality: the joint probability that the auditor found and } \\
\text { reported violations or anomalies in the financial statements of its } \\
\text { clients (De Angelo, 1981; Velnampy et al., 2014; Hapsoro, 2012; } \\
\text { Kane \& Velury, 2005). }\end{array}$ & $\begin{array}{l}\text { Dichotomy data on } \\
\text { grouping into the big four } \\
\text { audit firm or non-big four } \\
\text { audit firm (AudQlty). }\end{array}$ & Nominal \\
\hline
\end{tabular}

\subsection{Data Analysis Techniques}

In the present study, data analysis is conducted with the aid of second-generation statistical analysis tool of Structural Equation Modelling (SEM) with emphasis on Partial least square (PLS) approach. PLS is a robust analytical tool with fewer assumptions but has several advantages, namely: (1) Able to handle complex models with multiple exogenous and endogenous variables with many indicators. (2) Can manage data with multicollinearity issues between exogenous variables. (3) The results remain robust despite the noise of data and missing data. (4) Can be used on small sample size. (5) Does not require normally distributed data to be variable and (6) Can handle variables of nominal, ordinal and continuous types simultaneously (Hair et al., 2017). Hypothesis testing of the indirect effect of an independent audit committee member on the relationship between managerial ownership and independent board member and audit quality is carried out by utilising Sobel test statistical analysis for mediation. In Sobel test, the criteria for interpretation is $\alpha=0.05$, if $t$ value > critical value (i.e., 1.96), then the hypothesis is accepted or otherwise, rejected (Kline, 2010).

\section{RESULTS AND DISCUSSION}

\subsection{Descriptive Statistics}

Based on the sample criteria, this study adopted 29 banks with observation period from 2010 to 2015 . Therefore, 174 data are processed to obtain the conclusions based on the hypotheses testing. The descriptive statistics of the study is presented in Table 2.

Table 2. Descriptive Statistics of the study

\begin{tabular}{lccccc}
\hline & $\mathbf{N}$ & Minimum & Maximum & Mean & Std. Deviation \\
\hline MgrOwn & 174 & .0000 & 0.2823 & 0.0114 & 0.0367 \\
IndBodM & 174 & .0000 & 6.0000 & 2.9300 & 1.0837 \\
IndAudC & 174 & .0000 & 6.0000 & 2.2200 & 1.4258 \\
AudQlty & 174 & .0000 & 2.0000 & 0.6900 & 0.4640 \\
Valid N (listwise) & 174 & & & & \\
\hline
\end{tabular}


The results of descriptive statistics indicate that several banks do not have managerial ownership. According to Table 2, managerial ownership records $28.23 \%$ at maximum and the mean score of $1.14 \%$. There is no regulation that sets the minimum criteria for managerial ownership in Indonesia; but the higher managerial ownership, the higher the management's sense of belonging. Many banks in Indonesia do not have independent board member and independent audit committee as indicated in Table 2 with a mean score of 2.93 and 2.22 for independent board member and independent audit committee respectively. According to the rules and regulations in the banking companies in Indonesia, bank overseer needs to oversee the number of independent board member and independent audit committee. One of the requirements of the Indonesian Central Bank hinges on the bank board composition, which should consist of at least two independent members. Indonesian Financial Service Authority and the Indonesian Central Bank regulation state that the independent audit committee should consist of three persons or at least $51 \%$ of the total audit committee members. Having regards to the audit quality phenomenon, about $70 \%$ of banks operating in Indonesia engage the services of the big four audit firms with the hope of increasing the users' expectation of reliable and relevant financial statements.

\subsection{Assessing the Common Method Variance (CMV)}

The study adopts Harman's single factor analysis (Podsakoff \& Organ, 1986) being one of the most known techniques by researchers to resolve common method variance issues. The procedure involves the loading simultaneously all the constructs' variable into an exploratory factor analysis and examining the un-rotated factor solution to establish the number of factors that are necessary to account for the variance in the variables. In determining the existence of $\mathrm{CMV}$, the primary assumption states that "if a substantial amount of CMV exists, the results of the factor analysis could either be a single factor, or that a single factor causes the majority of the covariance in the dependent and independent variables" (Podsakoff et al., 2003).

Following, an un-rotated exploratory factor analysis of all the study items indicated 2 component factors in total which explains 64.5 per cent of the variance. The result of the total variance extracted is presented in Table 3. Granting that a single factor solution did not emerge, and a general factor is not reflected for most of the variance, common method variance is not regarded as a significant threat in this research (Podsakoff \& Organ, 1986).

Table 3. Total Variance Explained of the Study

\begin{tabular}{|c|c|c|c|c|c|c|c|c|c|}
\hline \multirow{2}{*}{ Component } & \multicolumn{3}{|c|}{ Initial Eigenvalues } & \multicolumn{3}{|c|}{$\begin{array}{c}\text { Extraction Sums of Squared } \\
\text { Loadings }\end{array}$} & \multicolumn{3}{|c|}{$\begin{array}{c}\text { Rotation Sums of Squared } \\
\text { Loadings }\end{array}$} \\
\hline & Total & $\begin{array}{c}\% \text { of } \\
\text { Variance }\end{array}$ & $\begin{array}{c}\text { Cumulative } \\
\%\end{array}$ & Total & $\begin{array}{c}\% \text { of } \\
\text { Variance }\end{array}$ & $\begin{array}{c}\text { Cumulative } \\
\%\end{array}$ & Total & $\begin{array}{c}\% \text { of } \\
\text { Variance }\end{array}$ & $\begin{array}{c}\text { Cumulative } \\
\%\end{array}$ \\
\hline 1 & 1.562 & 39.044 & 39.044 & 1.562 & 39.044 & 39.044 & 1.549 & 38.731 & 38.731 \\
\hline 2 & 1.018 & 25.455 & 64.499 & 1.018 & 25.455 & 64.499 & 1.031 & 25.769 & 64.499 \\
\hline 3 & .874 & 21.852 & 86.352 & & & & & & \\
\hline 4 & .546 & 13.648 & 100.000 & & & & & & \\
\hline
\end{tabular}

\subsection{Assessing the Coefficient of Determination $\left(R^{2}\right)$}

The coefficient of determination measures the model's predictive power. It represents the exogenous variables' (Managerial Ownership, Board Committee Independence and Audit Committee Independence) combined effects on the endogenous latent variable, Audit Quality). The $\mathrm{R}^{2}$ ranges from 0 to 1 as a measure of in-sample predictive power (Ringdon, 2012; Sarstedt, Ringle, Henseler, \& Hair, 2014). 
In this study, the Audit Committee Independence and the Audit Quality recorded $R^{2}$ values of 0.1049 and 0.1363 respectively. The result shows the amount of variance in Audit Quality explained by Managerial Ownership, Board Committee Independence and Audit Committee Independence of $13.63 \%$ is moderate. Furthermore, the amount of variance in Audit Committee Independence (i.e. the mediating constructs) explained by the Managerial Ownership and Board Committee Independence of $10.49 \%$ is moderate, and hence a significant measure of the model's predictive power.

\subsection{Assessing the Correlation Result}

The correlation between the variables can be found in Table 4. It is found that there is a weak and positive correlation between managerial ownership and the number of independent members of the audit committee. Managers, who are also the shareholders of the bank, indirectly contribute supervision by providing input to the board for increasing the number of independent audit committees. It is also found that an increase in the number of an independent board member is accompanied by an increase in the size of the independent audit committees with the magnitude of the relationship between the two variables is low. The number of independent members of the board will perform its function better by increasing the number of independent audit committees, which is believed to have better control of finance and accounting.

Table 4. Correlation Result

\begin{tabular}{lllc}
\hline & & & Correlation \\
\hline Managerial Ownership & $\rightarrow$ & Audit Quality & 0.0207 \\
Independent Board Member & $\rightarrow$ & Audit Quality & 0.3729 \\
Managerial Ownership & $\rightarrow$ & Independent Audit Committee & 0.0694 \\
Independent Board Member & $\rightarrow$ & Independent Audit Committee & 0.326 \\
Independent Audit Committee & $\rightarrow$ & Audit Quality & -0.0048 \\
\hline
\end{tabular}

An increase of managerial ownership is accompanied by a tendency to elect the public accounting firms beyond the big four on a low level of relationship. This suggests that the big amount of managerial ownership thus the manager who is also the owner of the bank will implement better internal controls and improvise supervision by the board and the audit committee, thus there is no need to perform audit engagement with big public accounting firms with high audit fees. An increase in the number of an independent board member is accompanied by an increase in audit quality with a medium level correlation. A large number of independent board member will have better financial supervision. On the occasions like this, the independent board member will cooperate with the audit committee to maintain the audit results, including the appointment of a large accounting firm to perform better audit quality.

This research also found that an increase in the size of the independent audit committee is accompanied by increased audit quality with a shallow level correlation. When the size of the independent audit committee increases, this particular committee will tend to increase supervision to obtain good audit results, which includes using sizeable public accounting firms in auditing the banks.

\subsection{Assessing the PLS-SEM Structural Model}

The processed PLS-SEM Bootstrapping structural model path analysis results are illustrated in Table 4, which shows the influence of managerial ownership and independent 
board member towards the independent audit committees and its implication on audit quality.

The PLS approach suggests that the hypothesis is accepted when $p$-value $<0.05$, with $\alpha$ $=5 \%$, or if the value of the $t$ statistic $>t$ critical value (1.96), otherwise the hypothesis is rejected. The results show that three hypotheses were rejected; the result is that managerial ownership does not significantly affect the independent audit committees and independent audit committee does not significantly affect audit quality (see Table 5). In more detail, the results of the path analysis test showed that the increase of managerial ownership does not significantly affect the increase in the number of independent audit committees to perform better financial supervision. With the high managerial ownership, the manager will conduct the better supervision and not rely on the appointment of a more substantial number of the independent audit committee. The result of this study is not accordance with the findings of Kane and Velury (2005), which found that the management who is also as the owner will perform better supervision through coordination with the board as the principal supervisor, including the appointment of a more significant number of the independent audit committee.

Table 5. Key Results of the PLS-SEM Bootstrapping Structural Model: Direct Effects

\begin{tabular}{clccccl}
\hline No. & Hypotheses & $\begin{array}{c}\text { Path } \\
\text { Coefficient }\end{array}$ & $\begin{array}{c}\text { Standard } \\
\text { Error }\end{array}$ & $\begin{array}{c}\text { T- } \\
\text { Statistics }\end{array}$ & P-Value & Decision \\
\hline 1 & MgrOwn $\rightarrow$ AudQlty & 0.0207 & 0.1407 & 0.147 & 0.883 & Not Supported \\
2 & BodCInd $\rightarrow$ AudQlty & 0.3729 & 0.0751 & 4.9678 & 0.000 & Supported \\
3 & MgrOwn $\rightarrow$ AudCInd & 0.0694 & 0.0606 & 1.1458 & 0.253 & Not Supported \\
4 & BodCInd $\rightarrow$ AudCInd & 0.326 & 0.0718 & 4.5374 & 0.000 & Supported \\
5 & AudCInd $\rightarrow$ AudQlty & -0.0048 & 0.0728 & 0.0656 & 0.948 & Not Supported \\
\hline Note: $95 \%$ Confidence Interval of the Direct effect & & & &
\end{tabular}

The increase in independent board member will affect the increase in the number of independent audit committees. The sizeable independent board member will give more concern on the supervision of financial statements report, resulting in the appointment of a larger independent audit committee. Baxter and Cotter (2009) and Kirkpatrick (2009) studies also found that independent board member appoints a more substantial number of independent audit committees in order to do better financial supervision.

On the other side, whenever managerial ownership is found to be high, the manager will implement better internal controls, including cooperating with the board and the audit committee. Based on this scenario, there is no need to perform audit engagement with big public audit firm with a high audit fee. This finding is contrary to Kane and Velury (2005) who suggested that high managerial ownership also increases company supervision, by using a big audit firm for quality audit services (Kane \& Velury, 2005).

The increase in some independent board member significantly affects the increase in audit quality. Hay et al., (2008) and Carcello et al., (2002) also found that the increase in the number of independent board member will have better cooperation with the audit committee in selecting the big public accounting firms to provide better audit quality. The increase in independent audit committee member does not significantly affect the increase in audit quality, which shown by engagement with big-four audit firms. This research found, through descriptive data, that there is no change in the size of independent audit committee member in banking company from year to year, so statistically, it has no significant impact on audit quality shown by the audit firm size. This research is not by the findings of Yasin and Nelson (2012), and Vlaminck and Sarens (2013) that sizeable 
independent audit committee work is more effective in supervising the finance and appointing an external auditor to generate reliable financial statement information that will result in better audit quality.

Table 6. Sobel Test Result for Indirect Effects

\begin{tabular}{|c|c|c|c|}
\hline & & 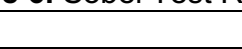 & T-Value \\
\hline MgrOwn & IndAudC & AudQIty & 1.099 \\
\hline IndBodM & IndAudC & AudQlty & 1.007 \\
\hline
\end{tabular}

The hypothesis testing results of indirect effect is stated in Table 6, and the Appendices to the study. In hypothesis testing of indirect effects, the impact of managerial ownership on audit quality through independent audit committee found $t(172)=1.099$, which is less than 1.96 (critical value) threshold. The result depicted that independent audit committee was not significant and as such cannot be a mediating variable on the relationship between managerial ownership and audit quality. Therefore, $\mathrm{H} 6$ is rejected. Similarly, the result of the mediating effect of audit committee independent on the relationship between board committee independent and audit quality was not significant. It revealed $t(172)=1.007$, which is less than 1.96 (critical value) threshold. Therefore, the audit committee independent does not mediate the relationship between board committee independent and audit quality in the Indonesian banking sector. Succinctly, Hypothesis $\mathrm{H} 7$ is not supported.

The audit committee was established to supervise management in presenting the financial statements, supervising the effectiveness of internal control implementation, and establishing excellent communication with external auditor to achieve the implementation of adequate and sound financial practices. The research data showed there was a tendency of banks in Indonesia used the same public accounting firm from year to year in their audit engagement. The data also showed the number and members of an independent audit committee from year to year tend not to change. Independent audit committee members who are too long in their duty have the potential to become less creative; their supervision function can be less optimal, so in this research, model found that independent audit committee member cannot mediate the impact of managerial ownership and independent board member on audit quality in banking company listed in IDX. It is necessary to improve the supervisory function of audit committee members, such as by refreshing their members and increasing the number of independent members to improve audit quality.

\subsection{Assessing the Process Partial Least Square Model of the study}

To confirm the robustness of the analysis, the authors in addition to PLS-SEM Bootstrapping for structural model embraced PROCESS Partial Least Square Version 3.00 (2018) by Andrew Hayes. The appendices to the study consist of the Process Partial Least Square generated output.

In the first part of the mediation model as contained in Appendix 1, the regression of board committee independent with the audit quality, ignoring the mediator (audit committee independent), was significant, $\beta=0.177, \mathrm{t}(172)=5.1994, \mathrm{p}=.000$. Furthermore, the regression of the board committee independent on the mediator, audit committee independent was also significant, $\beta=0.4165$, $t(172)=4.3767, p=.000$. Similarly, the mediation process showed that the mediator (audit committee independent), controlling for board committee independent was not significant, $\beta=.0012$, $t(172)=.0428, p=.9659$. 
The result of the analysis revealed that controlling for the mediator (audit committee independent), board committee independent scores was a significant predictor of audit quality, $\beta=.1775, \mathrm{t}(172)=4.9312, \mathrm{p}=.000$. The indirect effects of board committee independent (independent variable) on audit quality (endogenous variable) found no full mediation in the model $(t=0.0450, p=.9641)$. It was found that audit committee independent did not mediate the relationship between board committee independent and audit quality.

Finally, and in the second part of the mediation model as represented in Appendix 2, the regression of managerial ownership with the audit quality, ignoring the mediator (audit committee independent), was not significant, $\beta=.4272$, $t(172)=.3947, p=.6935$. In addition, the regression of the managerial ownership on the mediator, audit committee independent was not significant, $\beta=.9790, t(172)=.3302, p=.7416$. Similarly, the mediation process showed that the mediator (audit committee independent), controlling for managerial ownership was not significant, $\beta=.4682, t(172)=.4341, p=.6648$. Furthermore, the result of the analysis revealed that controlling for the mediator (audit committee independent), managerial ownership scores was not a significant predictor of audit quality, $\beta=.0418, \mathrm{t}(172)=1.5089, \mathrm{p}=.133$. The indirect effects of managerial ownership (exogenous latent variable) on audit quality (endogenous latent variable) found no full mediation in the model $(t=0.1663, p=0.868)$. It was found that audit committee independent did not mediate the relationship between managerial ownership and audit quality.

\section{CONCLUSIONS AND INTERPRETATION}

\subsection{Conclusions}

Based on the discussion and analysis conducted, the current study concluded that existing managerial ownership does not significantly affect the appointment of the independent audit committee, who is expected to perform better financial supervision in the listed banks on IDX. With the high managerial ownership, the manager conducts better supervision and not relying on the appointment of a considerable number of the independent audit committee. A large number of independent board member will have better supervision of financial statements and the tendency towards the appointment of a large number of the independent audit committee. A large number of an independent and objective board member as the supervisor can significantly affect the increase of the independent audit committee that will perform better financial supervision in the listed banks on IDX.

Managerial ownership is when the owner concurrently acts as the manager of the company. The increase in the size of managerial ownership will improve the supervision and thus reduce the audit costs because the audit committee will have the tendency not to choose the big-four audit firms. Managerial ownership has an impact on audit quality. The increase in the size of the independent board would have an impact on the higher concern of the importance of audit quality. A large number of independent board member will advise the audit committee to engage with the big four audit firms in auditing the financial statement. Independent board member has an impact on audit quality of the bank listed on IDX. The size of the independent audit committee does not significantly affect the audit quality, based on the size of the audit firm appointed, of banking companies listed on IDX. This study also found that there was no change in the number and membership of an independent audit committee from year to year; therefore statistically it has no significant impact on audit quality. 
Long task engagement can lead to boredom and lack of work creativity. It was found that there were many members of the independent audit committee that tend to remain unchanged from year to year, thus making the level of creativity became lower, the supervisory function decreased and less optimal. This study further found that independent audit committee members cannot mediate the impact of managerial ownership and independent board members on audit quality in banking company listed in IDX.

\subsection{Interpretation and Suggestion for Future Research}

It is necessary to improve the supervision on the appointment of independent board member and independent audit committee in banking companies in Indonesia because there were banks that have not met the requirements of Indonesian Bank regulations, namely to have at least two persons the independent board member. In regards of an independent audit committee, some banks have not met the Indonesia Financial Services Authority and the Indonesia Central Bank regulation that the independent audit committee should consist of least three persons or $51 \%$ of the total audit committee member.

Managerial ownership and the independent board member have a significant impact on the audit quality. This research is limited to finding the impact of managerial ownership and independent board member toward audit quality. It is necessary to conduct further research to find the ideal size of managerial ownership and the independent board member to be implemented in Indonesia to support and create a good quality audit. This research also finds that there is no significant impact between the independent audit committee toward audit quality because there was no change in the number and membership of independent audit committees during the period. This study showed, the independent audit committee members can not mediate the influence of managerial ownership and independent board members on audit quality. Further studies are needed to conduct to find out of what conditions or reasons can determine that independent audit committee members can be as a mediator to improve audit quality, so that would increase trust upon financial report to the users.

\section{ACKNOWLEDGEMENTS}

We would like to thank the Indonesia overseas seminar assistance program (BSLN), Ditjen Penguatan Riset dan Pengembangan, Kemenristekdikti who will fully fund us in this conference to get the best outcome. We are also grateful to anonymous reviewers of this paper who have provided very insightful advice.

\section{REFERENCES}

Adams, R. B. (2011). Governance and the Financial Crisis. International Review of Finance, 12(1), 7-38.

Adams, R., \& Mehran, H. (2008). Corporate performance, board structure, and their determinants in the banking industry.

Al-Hussain, A. H. (2009). Corporate Governance Structure Efficiency and Bank Performance in Saudi Arabia. (PhD. Thesis) The University of Phoenix.

Andres, P., \& Vallelado, E. (2008). Corporate Governance in Banking: The Role of the Board of Directors. Journal of Banking and Finance, 32(12), 2570-2580. 
Badan Pengawas Pasar Modal dan Lembaga Keuangan, Kementerian Keuangan Republik Indonesia. (2012). Salinan Keputusan Ketua Badan Pengawas Pasar Modal dan Lembaga Keuangan, No. Kep-643/BI/2012. Tentang Pembentukan dan Pedoman Pelaksanaan Kerja Komite Audit.

Balsam, S. (2002). Accrual Management, Investor Sophisticated, and Equity Valuation: Evidence from 10-Q Fillings. Journal of Accounting Research, 40(4), 987-1012.

Baxter, P., \& Cotter, J. (2009). Audit Committees and Earnings Quality. Accounting \& Finance, 49(2), 267-290.

Beisland, L.A., Mersland, R., \& Strom, R.O. (2015). Audit Quality and Corporate Governance: Evidence from the Microfinance Industry. International Journal of Auditing, 19(3), 218-237.

Belkaoui, A. R. (2004). Accounting Theory. Fifth Edition. London: Thomson.

Brooke, S. (2014). Seeking a Path Forward on Audit Quality Indicators: Audit Committees Play a Vital Role in Ensuring Audit Quality. The CPA Journal, 84(6), 8.

Carcello, J.V., Hermanson, D.R., Neal, T.L, \& Riley, R.A, Jr. (2002). Board Characteristics and Audit Fees. Contemporary Accounting Research, 19(3), 365-384

Choudhry, M. (2011). An Introduction to Banking: Liquidity Risk and Asset - Liability Management. $1^{\text {st }}$ edition. John Wiley and Sons.

Coles, L. J., Naveen, D. D., \& Naveen, L. (2008). Boards: Does one size fit all? Journal of Financial Economics, 87(2), 329-356.

De Angelo. L.E. (1981). Auditor Size and Audit Quality. Journal of Accounting and Economics, 3(3), 183-199

Docherty, A., \& Viort, F. (2014). Better Banking: Understanding and Addressing the Failures in Risk Management, Governance and Regulation. Hoboken: Wiley.

Favere Marchesi, M. (2000). Audit Quality in ASEAN. The International Journal of Accounting. 35(1), 121-149.

Fritz, M. S., \& MacKinnon, D. P. (2008). A Graphical Representation of the Mediated Effect. Behaviour Research Methods, 40(1), 55-60.

Graham, J.R., Sonali, H., \& Narasimhan, K. (2011). Corporate Governance, Debt, and Investment Policy during the Great Depression. Management Science, 57(12), 2083-2100.

Griffin, P., Lont, D., \& Sun, Y. (2008). Corporate Governance and Audit Fees: Evidence of Countervailing Relations. Journal of Contemporary Accounting and Economics, 4(1), 18-49.

Hagenbaugh, R. L. (2003). Current Issues: Corporate Governance and Sarbanes Oxley-What You Need to Know. Fraud Magazine.

Hamdan, A.M., Sarea, M.A., \& Reyad, S.M.R. (2013). The Impact of Audit Committee Characteristics on the Performance: Evidence from Jordan. International Management Review, 9(1), 32-42

Hapsoro, D. (2012). Pengaruh Corporate Governance dan Kualitas Audit Terhadap Pengungkapan Corporate Social Responsibility. Jurnal Akuntansi dan Manajemen, 23(3), 199-215.

Hair, J. F., Hult, G. T. M., Ringle, C. M., \& Sarstedt, M. (2017). A Primer on Partial Least Squares Structural Equation Modeling (PLS-SEM). 2nd Edition. Thousand Oaks: Sage.

Harris, M., \& Raviv, A. (2008). A Theory of Board Control and Size. The Review of Financial Studies, 21(4), 1797-1832.

Hay, D., Knechel, W., \& Ling, H. (2008). Evidence on the impact of internal control and corporate governance on audit fees. International Journal of Auditing, 12(1), 9-24. http://dx.doi.org/10.1111/j.1099-1123.2008.00367.x

Hermalin, B., Weisbach, M., (2003). Boards of directors as an endogenously determined institution: a survey of the economic literature, Federal Reserve Bank of New York Economic Policy Review, 9, 7-26.

Kane G D and Velury U (2005). The Impact of Managerial Ownership on the Likelihoodof Provision of High Quality Auditing Services, Review of Accounting and Finance, 4(2), 86-106

Kirkpatrick, G. (2009). The Corporate Governance Lessons from the Financial Crisis. OECD Journal: Financial Market Trends, 2009(1), 61-87.

Kline, R. B. (2010). Principles and practice of structural equation modeling (3rd ed.). New York: Guilford Press.

Kuncoro, M., \& Suharjono. (2012). Manajemen Perbankan: Teori dan Aplikasi. Edisi ke-2, Fakultas Ekonomika dan Bisnis UGM, Yogyakarta. 
Kusnadi, Y., Leong , K.S., Suwardy, T., \& Wang, J. (2016). Audit committees and financial reporting quality in Singapore. Journal of Business Ethics, 139(1), 197-214.

Lehn, K., Sukesh, P., \& Mengxin, Z. (2009). Determinants of the Size and Structure of Corporate Boards: 1935-2000. Financial Management, 38(4), 747-780.

Limpt, D.V. (2011). Management Ownership and Auditor Choice of Small and Medium Sized Firms in Germany. (MSc Thesis) Department of Accountancy, Faculty of Economics and Business Studies, Tilburg University, Germany.

McDaniel, L., Martin, R. \& Maines, L. (2002). Evaluating Financial Reporting Quality: the Effects of Financial Expertise vs. Financial Literacy. Journal of Accounting Review, 77, 139-167.

Mohamed, M. S., \& Mohamed, A. E. (2012). Corporate Governance Practices and Audit Quality: An Empirical Study of the Listed Companies in Egypt. World Academy of Science, Engineering and Technology, 71(1), 1292-1297.

Muhamad, R., Shahimi, S., Yahya, Y., \& Mahzan, N. (2009). Disclosure quality on governance issues in annual reports of Malaysian PLCs. International Business Research, 2(4), 61.

Murphy, M.L. (2014). Improving Audit Quality: An Interview with Cynthia M. Fornelli, an Executive Director of the Center for Audit Quality. The CPA Journal (February 2014).

Nakhodchari, F. S., \& Garkaz, M. (2014). Correlation Between Ownership Concentration, Voluntary Disclosure, and Information Asymmetry in Companies Listed in the Stock Exchange, Kuwait Chapter of Arabian Journal of Business and Management Review, 4(1), 423-432.

Nosheen, S. (2013). Impact of Board Leadership and Audit Quality on Disclosure Quality: Evidence from Pakistan. International Journal of Disclosure and Governance, 10(4), 311-327

Otoritas Jasa Keuangan- Republik Indonesia. (2014). Salinan Peraturan Otoritas Jasa Keuangan N0. 55 /POJK.04/2015, Tentang Direksi dan Dewan Komisaris Emiten atau Perusahaan Publik. Retrieved from http://www.komiteaudit.or.id/wp-content/uploads/2017/07/POJK-55.Pembentukan-dan-Pedoman-Pelaksanaan-Kerja-Komite-Audit.pdf on 2 October 2017.

Peni, E. \& Vähämaa, S. (2012). Did Good Corporate Governance Improve Bank Performance during the Financial Crisis? Journal of Financial Services Research, 41(1), 19-35.

Popoola, O. M. J. (2014). Forensic Accountants, Auditors, and Fraud: Capability and Competence requirements in the Nigerian Public Sector. (PhD. Thesis), Othman Yeop Abdullah Graduate School of Business, Universiti Utara Malaysia, Malaysia.

Rachdi, H., \& Ameur, I.G.B. (2011). Board Characteristics, Performance and Risk Taking Behaviour in Tunisian Banks. International Journal of Business and Management, 6(6), 88-97.

Rouf. A. (2011). Corporate Characteristics, Governance Attributes and the extent of voluntary disclosure in Bangladesh. African Journal of Business Management, 5(19), 7836-7845.

Santanu, M., Hossain, M., \& Deis, D. R. (2007). The Empirical Relationship Between Ownership Characteristics and Audit Fees. Review of Quantitative Finance and Accounting, 28(3), 257285

Sekaran, U., \& Bougie, R. (2010). Research methods for business: A skill-building approach (5th ed.). Haddington: John Wiley \& Sons.

Shen, C. H., \& Chih, H. L. (2007). Earnings Management and Corporate Governance in Asia's Emerging Markets. Corporate Governance: An International Review, 15(5), 999-1021.

Silveira, A.D.M.D., \& Barros, L.A.B.D.C. (2006). Corporate Governance Quality and Firm Value in Brazil). Available at SSRN: https://ssrn.com/abstract $=923310$ or http://dx.doi.org/10.2139/ssrn.923310

Sreejesh, S., Mohapatra, S., \& Anusree, M.R. (2014). Business Research Methods: An Applied Orientation. Springer International Publishing Switzerland. XXIII, 281, doi:10.1007/978-3-31900539-3.

Sudsomboon S. and Vssahawanitchakit P. (2009), Professional audit competencies: The effect on THAI"S CPAs audit quality, reputation, and success, Review of Business Research, 9(3), 6685.

Subramanyam, K. R. (2014). Financial Statement Analysis. 11 ${ }^{\text {th }}$ edition. McGraw-Hill, New York. 816 pages

Taqi, M. (2013). Consequences of Audit Quality in Signaling Theory Perspective. GSTF Journal on Business Review (GBR), 2(4), 133-136. 
Velnampy, T., Sivathaasan, N., Tharanika, R. \& Sinthuja, M. (2014). Board Leadership Structure, Audit Committee and Audit Quality: Evidence from Manufacturing Companies in Sri Lanka. International Journal of Business and Management, 9(4), 76.

Vlaminck, D. N., \& Sarens, G. (2013). The relationship between audit committee characteristics and financial statement quality: Evidence from Belgium. Journal of Management \& Governance, 19(1), 145-166.

Wahba, H. (2014). Capital structure, managerial ownership and firm performance: evidence from Egypt. Journal of Management \& Governance, 18(4), 1041-1061.

Yasin F. M., \& Nelson S. P. (2012) Audit committee and internal auditing: Implication on audit quality. Journal of Economic Management and Accounting, 20(2), 187-218. 
Examining the Independent Audit Committee, Managerial Ownership, Independent Board Member and Audit Quality in Listed Banks

\section{APPENDICES}

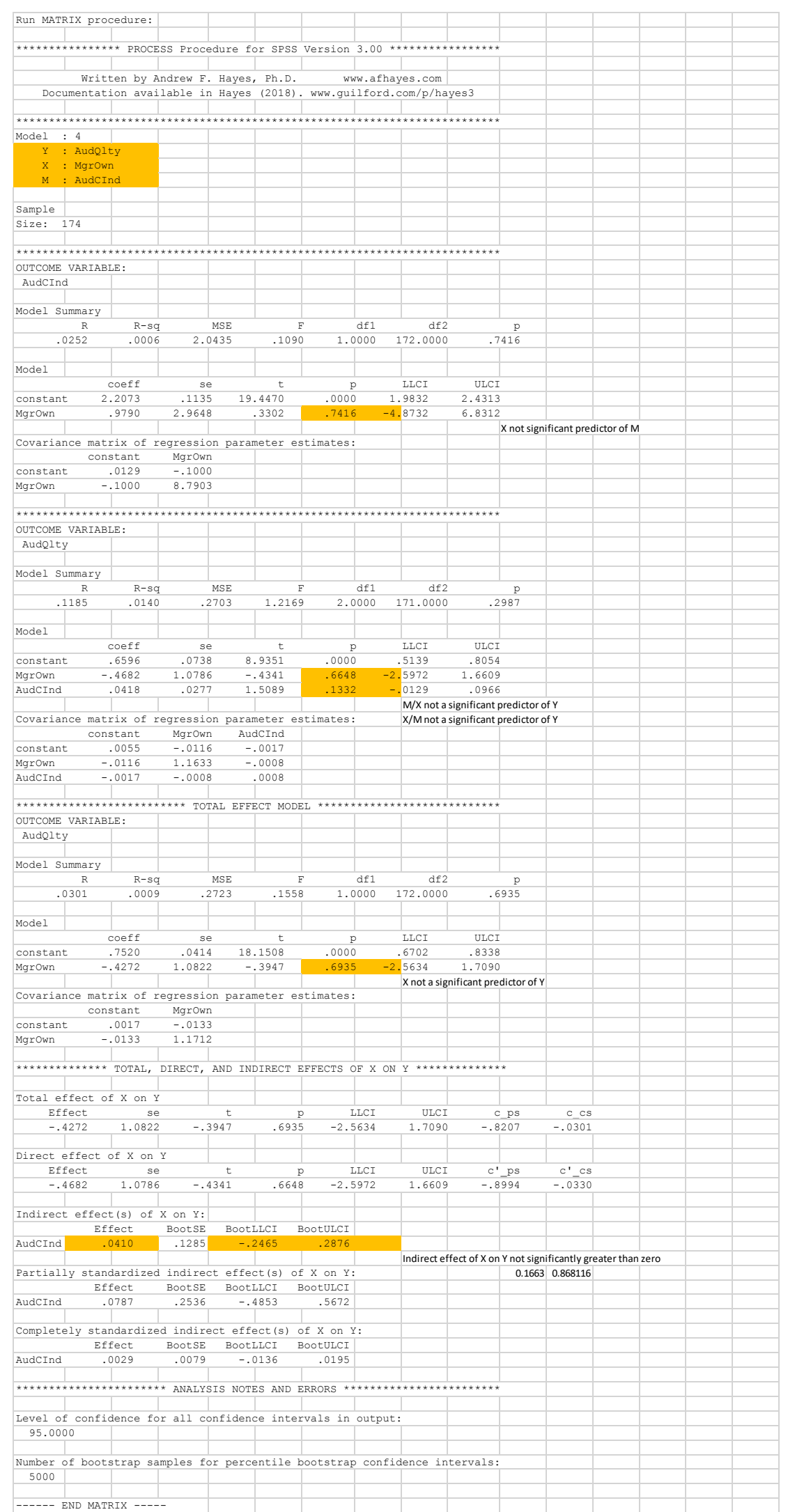


Pangaribuan, H., Sihombing, J., \& Popoola, O. M. J.

\section{APPENDICES Cont'd}

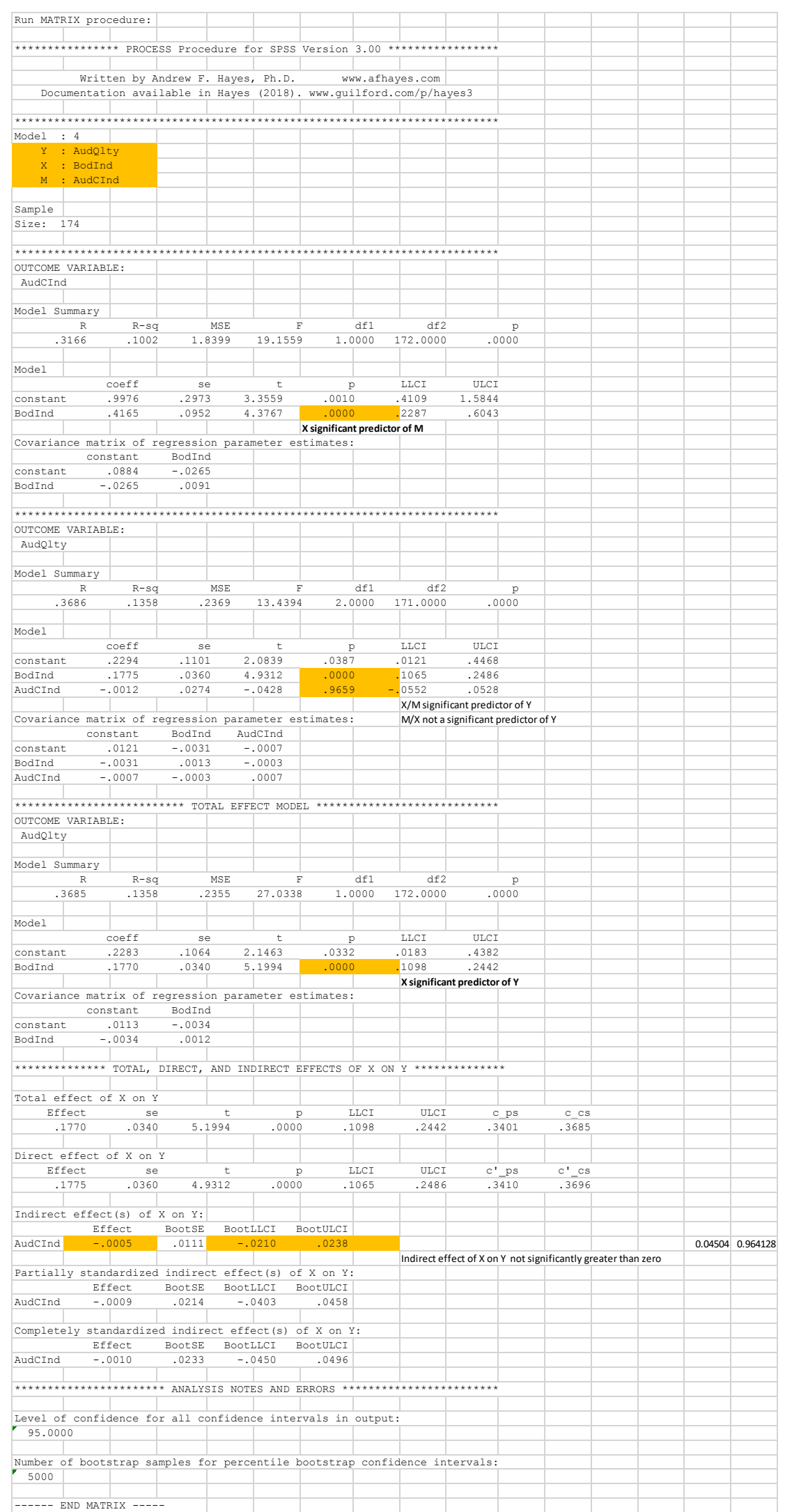

